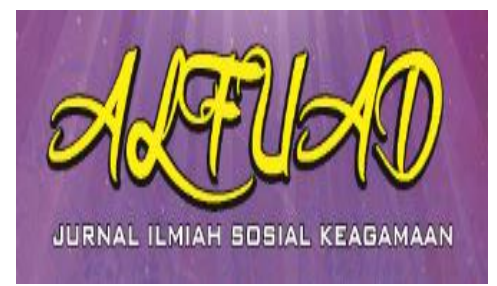

ALFUAD JOURNAL, 5 (2), 2021,(38-50)

(E-ISSN 2714-7606 P-ISSN 2614-4786 )

Available online at

http://ecampus.iainbatusangkar.ac.id/ojs/index.php/alfuad

\title{
The Role of The Family in Responding to Radical Ideologies
}

\section{Dewi Nur Aeni*)}

UIN Prof. K.H. Saiffudin Zuhri, Indonesia

E-mail: dewinuraeni701@gmail.com

\section{Ais Chusniati}

UIN Prof. K.H. Saiffudin Zuhri, Indonesia

E-mail: aischusniati15@gmail.com

\section{Duta Sukma Yoga}

UIN Prof. K.H. Saiffudin Zuhri, Indonesia

E-mail: Yogabae161@gmail.com

\section{Faiqotun Khasanah}

UIN Prof. K.H. Saiffudin Zuhri, Indonesia

E-mail: faiqotunhasanah@gmail.com

\begin{abstract}
This study aims to describe and analyze what efforts can be made by families regarding their role against radical ideology in children. The role of the family is the first step that can be taken and usually implemented in the form of fostering and inculcating contextual religious teachings from an early age. In the family, the role of parents is prioritized because they are the ones who play an active role in the character building, personality, and morality of children. So that children can distinguish between good and bad things in the process of growth and development. Thus, children can avoid the influence of radical ideologies that develop in society. In this study, the authors use journal literature and effective data that are relevant to the problem, namely the role of the family against a radical ideology which then qualitatively explains the result that we got. The results of this study illustrate the importance of the role of the family, that is parents in raising children by inculcating the values that need to be taught to children, and the efforts made by families in countering radicalism.
\end{abstract}

\section{Yessica Dwi Elvira}

UIN Prof. K.H. Saiffudin Zuhri,

Indonesia

E-mail: elvirayessica8@gmail.com

*) Corresponding Author

Keywords: Radicalism, Ideology, Family, Values, Prevention

\section{INTRODUCTION}

The rise of radicalism cases lately has led to the development of understanding or even issues of radicalism, for example, such as suicide bombings, terrorism, and the formation of deviant groups such as the ISIS and al-Qaeda network groups, which later became a global issue. The existence of these groups, as a form of great opposition from radical
Islamic groups according to them life is unfair and the existing rules are not in line with the principles of their group, then the issues spread briefly via the internet to various countries.

Radical comes from the word radix which means root, source, and origin. Then the term radical refers to the foundation, basic principles, and themes that are essential for various phenomena, or it can 
also mean "unconventional" (unconventional). While radicalism is the teaching or practice of the adherents of radical ideas. According to the KBBI, radicalism means an understanding, sect, or teaching that wants a change both socially and politically through violence, extreme and drastic.

Experts reveal that radicalism is defined as a desire to make ideological changes (ideas or ideas) by using violent or extreme means in social and political systems (Laik, 2018). In essence, radicalism is an attitude or action to make the desired change, carried out by individuals or groups using violent means. Changes in a short and drastic way are what radical groups want, and are also accompanied by a desire to make changes that are contrary to the current system. The term "radical" was first introduced around 1797 by Charles James Fox (Laik, 2018). Precisely when the system of government in England, Charles called for a Radical Reformation movement. So that the movement was used to solve a problem at that time, which ended with the development of mixing between radical ideology and the ideology of liberalism.

Radicalism can also be interpreted as an act or view that is extreme, militant and tends to require a shift from what society is currently embracing. Radicalism is not only in the form of physical violence, but various ideologies, understandings, opposing thoughts can also be categorized as radical attitudes.

The impact now is the increasing development of radical cases in society, so this certainly needs special attention, not only from the government but all levels of society must play a role, especially a family, namely parents. In an effort to prevent radicalism, of course, a broad and precise strategy is needed. Starting from prevention steps, then handling steps, and up to steps to enforce the law. For example, in the application of preventive measures, it can be started from the environment which essentially has an important role in preventing the emergence of seed s of radicalism, namely the family.

The family can be interpreted as the first and main educational institution for a child in his life, which later becomes an important foundation for the formation of one's own character. To make children have strong characters and good souls, it is necessary to create a harmonious and energetic family atmosphere, so that good relationships and communication are established between parents and children. (Hyoscyamina, 2011).

To prevent the emergence of radicalism, it is tantamount to trying to detect the spread of radicalism, which can be started from the smallest part of society, namely the family environment (Tarwilah, 
2020). The role of parents is indeed required to be the main protector for their children from all dangers, including from the dangers of radicalism. Basically, children do a lot of activities and it is appropriate for parents to monitor and supervise them so that if children do activities that look deviant or unnatural, parents can prevent them. Therefore, the main key in countering radicalism is the supervision and sensitivity of parents to children's activities.

For families, the radicalism movement is considered to be a challenge that must be faced especially by parents. Because to avoid being influenced by children into radicalism, the role of the family is needed as a control over what a child needs to absorb and learn. Thus, good cooperation between parents, namely husband and wife when providing learning to children is also needed. This is intended so that the implementation of the prevention of radicalism is more effective.

In addition, efforts to counteract or prevent the expansion of radicalism that develops in society can be carried out by the family, because the family is the closest environment for a child, and the family environment is a place for a child to start his life and start his interaction activities. The family environment is also considered to be the main because the activities carried out by children are mostly carried out within the family environment itself, including education regarding the values of life or moral, social, religious education, and others. Education like this will shape the personality of the child, so parents need to play an active role in it.

Until now, the role of the family is still often ignored in relation to the problem of radicalism. In fact, from most cases of radicalism or the spread of radical ideas, it is young people who often fall. This is because parents pay less attention to their children, so that children feel neglected and unloved. As a result of this lack of attention, it is possible to enter the notion of radicalism in children. Because for children, a concern is an encouragement for him and proof that he is accepted or considered to exist. Children who lack attention, will be rebellious, stubborn, and finally find their identity in a place that is able to accept them.

In the family environment, the inculcation of basic thinking values in children such as tolerance, harmony, friendliness and other good things, should be used as a strategic and efficient means by the family (Tarwilah, 2020). Because, in the family social interaction is first implemented and becomes the first social environment which will subsequently affect the formation of character, character and mentality in children. Therefore, parents should understand various things 
related to the preparation of learning about radical ideology.

This learning is intended so that children will not be affected by radicalism that leads to untruth. For example, the emergence of a radical thought in someone in the field of religion, the factor that causes it is the lack of understanding or the narrowness of religious knowledge possessed by the child's parents. Therefore, the efforts of parents in instilling or teaching religion to children from an early age require qualified skills and knowledge, so that their children will understand religious knowledge widely.

On the one hand, the radicalism movement is growing rapidly with various kinds of actions, both physical actions and the spread of ideologies, or deviant and extreme understandings. But actually, the spread of radicalism itself can be prevented and anticipated starting from the smallest unit in society which is the place where a person first interacts and develops, namely the family. That's what makes the writer interested in researching this problem because not many people are aware and understand about the role of the family in preventing radicalism.

The formulation of the problems in this study are as follows: First, what is the role of the family in preventing radicalism. Second, what are the values that are applied as a form of preventing radicalism in children. Third, what are the ways for parents to counteract radicalism in their children.

\section{METHOD}

The method in this study uses a descriptive qualitative method, which is a method whose function is to describe and analyze a result of research that has been carried out, but the conclusions produced are not broad (Sugiyono, 2005). Descriptive method is also an interpretation of finding a fact in the field (Whitney, 1960). In the research that has been done, the authors make observations of the situation and conditions based on the media to be analyzed. In addition, the author also analyzes the social conditions in society where this condition is related to the problem of radicalism and the handling that can be done in the family environment. These problems include finding out what roles the family can play in countering radical ideology, the values that are applied as a form of preventing radicalism in children, and how parents can prevent radicalism in children, which are then interpreted into writing. The author also looks for what roles families can play in preventing radicalism itself, examines the values that children need as an effort to prevent radicalism, as well as what ways parents need to do to their 
children in preventing radicalism, which then interprets it into a writing.

In this study, all types of references used by the author were taken through books, scientific journals, and various reference sources originating from electronic media, which in turn resulted in a new scientific paper. The results of this new scientific work are obtained by looking for references, reading these references, and then references or library materials from the results of research reports that have been previously searched for, first analyzed and reviewed.

\section{RESULT AND DISCUSSION}

\section{The Role of the Family in Countering Radicalism}

Family life that is lived in harmony will later give birth to a positive impact on the survival of the family, especially for the baby (children) for the sake of the integrity of the household (Zidni, 2018). Therefore, to realize a harmonious life, cooperation between father and mother is needed, both in terms of equal rights, obligations, degrees, roles, positions, and in other fields. Between the wife and husband must complement and complement each other in all daily activities, live life with mutual respect, respect, and do not worry about differences of opinion or when experiencing problems do not feel right alone, must be able to understand one party in order to create a calm and peace in your dream home life.

In family life, good cooperation, in its implementation, must be enjoyed by all residents of the family, whether mother, child, or father, including the closest environment, if each party can enjoy harmony in it, then with this they will be able to maintain and avoid things bad things for children, especially from cases of radicalism (Zidni, 2018).

The smallest education in the sphere of life, namely the family, which has an important influence on the formation of children's character, especially in religious disciplines, this is where the role of parents is required to always work together in directing and educating children. The understanding of religion that parents give to children is not only textual or normative-formal related to worship, but also contextual understanding in the hope that it will provide good examples such as mutual respect between religious communities, because most of what is happening today children tend to be pious. in worship but not accompanied by social actions that reflect peace, such as radicalism which is very dangerous for the future of children as the determining generation for a better future in the country. Therefore, mothers and fathers must really be role models for their families to shape their offspring's 
personality in religion as well as wider social behavior. may even be able to prevent him from radical ideas and practices of radicalism.

Parents should be a place that continuously strengthens the relationship of approach and persuasive communication to their children to always supervise and pay attention to all forms of children's activities, such as: supervising all activities both at school and when playing with friends. friends at home, checking and sorting the channels or sites they watch, and so on whether they are in accordance with existing norms, do not contain radical elements that will lead children to intolerant attitudes, must also be accompanied by examples that contain values. positive and moderate, providing understanding or information related to radicals and the consequences of these radical practices, as well as providing advice on the beauty of living a religious life that is focused on rahmatan lil'alamin.

The figure of the mother has a major role in shaping the personality of children, equipping them when entering a wider scope in society and when they are married themselves, and is able to form a person who develops well and is reasonable to be seen and becomes the support of his life and soul.

Such a thing will be realized if both, namely the father and mother are able to provide an example of moderate behavior, not taking sides with one party, impartial, namely being able to be fair in all decisions. For example, a father who gives opportunities only to his sons, not to daughters. This will cause jealousy, even children who feel they are being treated unfairly so that later they will fight back by rebelling and intolerance. Therefore, both fathers and mothers are emphasized to always be moderate and not inclined to either son or daughter, in order to avoid these unwanted things.

In Islam, it is explained that children are like white paper that has not been tarnished, as has been explained in a hadith, that the Messenger of Allah said, "Every child who is born pure (fitrah), it is his parents who make him a Jew, a Christian, even a Magian" (HR. Bukhari \& Muslim) (Zidni, 2018). The ideals of children in the future are the most important, therefore, depending on the stimulus given in the family environment to him, both positive and negative. So both parents have a mandate in the success of their children in the future.

The appropriate way of upbringing, namely democratically, is able to become a place for deradicalism, not only cooperation between mothers and fathers, but also between communication and control between children, mothers and fathers (Zidni, 2018). The definition of 
democratic parenting is that fathers and mothers treat them with full control accompanied by maximum warmth. parents always motivate their children, appreciate their behavior and always guide them. Giving freedom to their children, coupled with making agreements during family discussions, children must be disciplined in all things, give sanctions according to decisions that have been made, correct mistakes made by their children but not in a way that is restrained. Give strict punishment if the child makes a very fatal mistake. In this style or way of parenting, parents must be fully aware of being parents and are considered adults who have a duty to educate their children and always do not feel that parents are always right, because in truth parents are also creatures of God and are different from angels who never wrong or forget, in order to build a quality child's personality in the future. And also, parents must graciously accept input and wishes from their children so that they can keep children from being intolerant, parental behavior like this is able to provide a child's mindset regarding the nature of respecting different opinions and being democratic in behavior and good in attitude so that they are kept away from rude, coercive, even radical mind set.

The family is a support for the existence of a nation (Azmi, A. 2019).
When the supports are deformed, broken and destroyed, then the wall of the nation's building loses its solid foundation to stand upright. From within the family, the next generation of the nation is born, and is the beginning of an important activity center in the elements of life. A family who always nurtures, teaches, guides, and also realizes the importance of intuition to maintain the strength of a nation and state. Therefore, the smallest institution in society, namely the family, will always provide positive encouragement for the realization of the unity and integrity of the Unitary Republic of Indonesia.

\section{Values Taught as a Form of Countering Radicalism in Children}

Education in the family is also the main and important thing in the formation of character in children. Family partnerships in educating children's character are the initial foundation that can be used as a foothold in dealing with life's problems (Zidni, 2018). Partnership in the family will work properly if it is supported by all the families who live together and participate, so that the family becomes harmonious which can later teach children to avoid radicalism deviations. For this reason, it is necessary to have values to counteract the existence of radicalism in children. The following are values that can be taught to children as a step to counter 
radicalism (Anwar, 2021): (1) Values to Increase National Commitment. Love for the homeland, and the spirit of nationalism can be applied from an early age in order to increase the loyalty of a nation. National loyalty that applies a sense of respect for the nation, and the spirit of nationalism in preserving prosperity can make the nation strong. Instilling the value of national commitment can provide understanding and knowledge about the values in Pancasila, the values in the 1945 Constitution, the function and purpose of the Unitary State of the Republic of Indonesia, and can know the motto of our country, namely Bhinneka Tunggal Ika. This commitment can be made to children by providing domestic products, this is to convince children that the nation itself can produce its own works with the best quality, as well as to create a sense of pride in their own nation. In addition, instilling an attitude of nationalism and patriotism can also be done to increase national commitment so that children can imitate this in accordance with what is taught by their parents.

(2) Introduction to the Value of Diversity. The introduction of the value of diversity can be instilled through flag ceremonies, singing regional and national anthems, national insight, introduction to the nation's cultural diversity, introduction to the wealth of natural resources and so on as a form of bringing out the love for the homeland that is instilled through diversity. This can be instilled from an early age, so that children can know that the Indonesian state has diversity in culture, ethnicity, religion and so on.

(3) Instilling the Value of Tolerance. The language of tolerance comes from the word "tolerance" which means to let. Meanwhile, in the Big Indonesian Dictionary, it means a trait or behavior to be tolerant (KBBI). Tolerance can be interpreted as an attitude of respecting each other's opinions and helping each other.

Families can apply an attitude of tolerance to children from an early age, which can be done by exemplifying things from the smallest first, such as helping parents in doing homework; mutual respect and love for fellow family members; if parents give advice is heard and implemented properly; do not disobey parental orders, and so on. The principle of tolerance can be said to be a unified principle, with integrity, and upholding values in uniting the nation.

(4) Understanding Human Values. Children need to be directed in understanding human values. This can be practiced through the attitude of smiling, greeting, greeting, polite, and courteous. To understand the value of humanity, it can be emphasized to children that 
community relations between adherents of one religion to another can be based on the peace of human conscience. Families can provide knowledge to children that religion upholds human values, peace and does not impose its will on others.

(5) Reflecting the Value of Local Wisdom. The word local wisdom consists of two words, namely wisdom (wisdom) which means wise and local (local) means local (Aditya, 2021). Local wisdom is a value that is reflected in the community environment that can be used as a reference in the daily behavior of people in general. In the family, local wisdom can be introduced to children, in the form of the uniqueness of their respective regional cultural products, but it can also reflect norms that are in accordance with the community environment. Local wisdom taught to children must be in accordance with the values of politeness, mutual cooperation, tepa slira, togetherness, maintaining good harmony between fellow communities, and so on. Local wisdom is good for the development of character education in children, because it can teach children to be able to deal with various situations and problems in everyday life, which later if instilled in children will become a culture that can make traditions and foster a conservative attitude.

The role of the family as a protection and shield for children by providing roles and values that can counteract the radicalism movement that occurs in children. Roles in family partnerships can also shape and grow character in children in countering the existence of radicalism movements. Radicalism movements can be prevented as early as possible, with the role of a harmonious family, which always instills values that can be taught to children as a step to counteract radicalism. The understanding of religion in the family also plays a very important role in this case, religion towards existing social behavior.

\section{Parents' Ways to Counter Radicalism in Children}

Along with the development of technology and globalization, whether we realize it or not, radicalism has begun to reach the scope of children. If you pay attention to it whether you realize it or not, when children enter the age who start to group, it is actually the beginning of the practice of radicalism. Radicalism should only be food for parents. Children in the golden age are children between the ages of zero to six years, this is a period where children are in a period of abstract cognitive and mental development, so they are prone to being influenced by the outside world (Rosyida Nurul Anwar, 2019), Values that need to be instilled during the golden age in children, namely 
in the form of wasathiyah Islamic character values that lead to aspects of equality, mutual respect for each other (tolerant), moderate Islam that needs to be instilled in early childhood children, namely in the form of inculcating moderate Islamic character values that are in the aspect of equality. , tolerance, liberation, humanity, pluralism, sensitivity, non-discrimination (Wahab, 2019). In the early education process, there are four things that need to be internalized and developed, namely mutual respect for others, not favoritism, equality (Mahmudi, 2018).

Along with the development of technology and the involvement of children in various recent events, it has drawn sympathy from various circles. Of the various events that suck the sympathy of various parties, here the family, especially the parents, is the party who plays the most important role in it. the incident and the many kinds of incidents involving children, gradually became the attention of many parties. Parents must play a major role in children's lives related to radicalism, because children's understanding of something is influenced by how parents understand it. Parents must also understand and understand understandings that can trigger radicalism, one of which is an understanding of religion, parents have a role to instill moderate religious knowledge. Parents should also monitor the religious knowledge that their children get is good and deep religious knowledge. good, loving others, and religious knowledge is obtained from people whose knowledge has been recognized as scholars. In addition, parents also need to introduce and instill the values of diversity or multiculturalism so that Indonesia adheres to diversity. (Ahmad Yani, 2020).

Every parent must have a variety of parenting patterns, some follow the parenting method of their previous parents, and some use parenting methods that have become the principle. There are many ways and methods that parents can do to introduce radicalism to their children, so that they can be understood and accepted properly. Below are various methods that parents can use: (1) Provide a valid and comprehensive understanding of religion. There should be no understanding that causes the mind to become compartmentalized and limits the child's ability to blend in with diversity and difference. Give the child an understanding that religion brings peace, not peace, it doesn't destroy culture. Provide safe environmental conditions for children so that they become good religious adherents and realize empirical diversity.

(2) Strengthening the function of Pancasila as the state ideology in its application to the practice of daily life. For 
example: Congratulations in religious celebrations to adherents of other religions is a practice of the first precepts of Pacasila. (3) Provide understanding to children about the dangers of radicalism. (4) Showing the community's progress in addition to being a source of information, which can be positive but can also be negative.

Indeed, parents are the first role model for a child (role model). So, parents must maintain stability between words and actions, because children are very good observers. They observe the stability of the speech and activities of the people around them, especially their parents.

\section{CONCLUSION}

The rise of radicalism that is happening in Indonesia today, has in fact become a dangerous threat because it can destroy the unity and integrity of the country. Where the perpetrators of radicalism are Indonesian citizens, both from teenagers to adults who have fallen into the notions of deviant sects. It does not necessarily take the form of physical violence, but an invitation or call to join can also be interpreted as an attitude of radicalism.

Thus, efforts should be made to prevent radicalism so that the problem of radicalism does not develop more widely. To realize it, the role of the government alone is not enough, but the cooperation of the community in eradicating radicalism is very much needed. Especially the role of the family as a preventive effort which is considered to be able to prevent the growth of seeds of radicalism, because in the family environment the forerunner of personality, religious teachings, behavior, values of life have been instilled from an early age.

The values of life that are instilled as a form of counteracting radical ideology in children are a) instilling a national commitment as a form of providing knowledge and understanding related to the four pillars of the nation's foundation; b) the value of diversity to know that ethnic diversity, religious differences, and various cultures are owned by the Indonesian people; c) tolerance or behavior respecting the thoughts and opinions of someone who is different from ours; d) human values that can be practiced through $5 \mathrm{~S}$ cultural attitudes (smile, greeting, greeting, polite, courteous); and, e) behave by using local wisdom as a reference in their daily life in the community.

The existence of a family upbringing pattern by providing values that can prevent radicalism, introducing children to radicalism, and providing an understanding of religion that is contextual and has implications for social behavior, is considered to be able to shape and grow 
the child's character to become a person who is more resistant to the entry of radicalism. in self. In other words, the role of the family is very important in preventing radicalism. Where as parents, at least take part in overcoming problems and there is a need for a more understanding of radicalism so that their families and children do not get involved in the influence of this understanding.

\section{REFERENCES}

Aditya, R. (2021). Pengertian Kearifan Lokal oleh Para Ahli. Retrieved from Suara.com:

https://www.suara.com/news/2021/ 01/07/130125/pengertian-kearifanlokal-oleh-para-ahli?page $=$ all (Accessed 18 Juni 2021).

Anwar, R. N. Y. D. (2019). Peran Pendidikan Anak Perempuan Dalam Membentuk Masyarakat Madani. Jurnal Care, 6 (2), 11-18.

Anwar, R. N. (2021). Penanaman NilaiNilai Islam Moderat Pada Anak Usia Dini Dalam Keluarga Sebagai Upaya Menangkal Radikalisme. Early Childhood Islamic Education. 4 (2), 156-162.

Azmi, A. (2019). Pengelolaan Arsip Keluarga: Suatu Kajian Kearsipan. Jurnal Kearsipan, 10 (1), 9-26.

Harahap, S. (2017). Upaya Kolektif Mencegah Radikalisme dan Terorisme. Depok: Siraja.

Hyoscyamina, D. E. (2011). Peran Keluarga Dalam Membangun Karakter Anak. Jurnal Psikologi Undip, 10 (2), 144-152.
KBBI. co.id (2014). Arti Kata: Arti Kata radikalisme Menurut KBBI. Retrieved from https:/kbbi.co.id/arti-kata/radikalisme (Accessed 18 Juni 2021).

KBBI. co.id (2014). Arti Kata: Arti Kata toleransi Menurut KBBI. Retrieved from https:/kbbi.co.id/arti-kata/toleransi (Accessed 18 Juni 2021).

Kurniawan, I. (2020). Memamknai Radikalisme Di Indonesia. Jurnal Studi Pendidikan Islam, 3(1), 7082.

Laik, M. M. (2018). Peran Orang Tua dalam Mengantisipasi Radikalisme pada Anak. Revitalisasi Indonesia Melalui Identitas Kemajemukan Berdasarkan Pancasila. UKI Press, Pusat Studi Lintas Agama dan Budaya UKI Lembaga Penelitian dan Pengabdian Kepada Masyarakat UKI Magister Pendidikan Agama Kristen UKI, pp. 246-254. Retrieved Juni 20, 2021, from

http://repository.uki.ac.id/841/

Ma'arif, H. N. (2016). Baiti Jannati Sebagai Penangkal Radikalisme Anak. Retrieved from http://jalandamai.org/baiti-jannatisebagai-pen angkal-radikalismeanak.html (Accesed 15 Juni 2021).

Mahmudi. (2018). Islam Moderat Sebagai Penangkal Radikalisme: Studi Terhadap Pemikiran Abdurrahman Wahid Dan Quraish Shihab. In Proceedings Annual Conference for Muslim Scholars Kopertais Wilayah IV Surabaya. Retrieved Juni 20, 2021, from http://www.kopertais4.or.id/ 
Musyafak, N. U. M. (2020). Peran Perempuan Dalam Pencegahan Radikalisme. Jurnal Dakwah, Vol. 21, No. 1 .

Rakhmawati, I. (2015). Peran Keluarga dalam Pengasuhan anak. KONSELING RELIGI Jurnal Bimbingan Konseling Islam, 3 (1), $1-18$.

Satriawan, I. M. N. (2019). Pencegahan Gerakan Radikalisme melalui Penanaman Ideologi Pancasila dan Budaya Sadar Konstitusi Berbasis Komunitas. Jurnal Surya Masyarakat, Vol. 1, No. 2.

Sugiyono. (2005). Metode Penelitian Administrasi. Bandung: Alfabeta.

Tarwilah. (2020). Keluarga Benteng Utama Mencegah Radikalisme. Retrieved from https://www.uinantasari.ac.id/keluarga-benteng-utamamencegah-radikalisme/ (Accesed 15 Juni 2021).

Wahab, G. (2019) Penanaman Nilai-Nilai Karakter Islam Moderat Pada Anak Usia Dini Di RA DWP IAIN Palu, Jurnal Pendidikan Anak, 1 (1), 1740.

Whitney, F. 1960. The Element of Research. New York: PrenticeHall, Inc.

Widyaningsih, R. K. M. (2020). Community-based Prevention of Radicalism: Psychosocial Perspective of Radicalism in Indonesia.

Widyaningsih, R. S. M. (2019). Deteksi Dini Radikalisme. Purwokerto: Lembaga Penelitian dan Pengabdian Kepada Masyarakat Universitas Jenderal Soedirman.

Widyaningsih, R. S. S. (n.d.). (2017). Kerentanan Radikalisme Agama. Prosiding Seminar Nasional dan
Call for Papers "Pengembangan Sumber Daya Perdesaan dan Kearifan Lokal Berkelanjutan VII". Retrieved Juni 20, 2021, from http://jurnal.lppm.unsoed.ac.id/ojs/i ndex.php/Prosiding/article/view/55 $\underline{3}$

Yani, A. J. J. (2020). Penyelenggaraan PAUD Berbasis Karakter Kebhinekaan Sebagai Upaya Pencegahan Radikalisme Sejak Dini. Obsesi: Jurnal Pendidikan Anak Usia Dini, 5 (1), 1-13.

Zidni, E. S. S. (2018). Kemitraan Keluarga dalam Menangkal Radikalisme. Jurnal Studi Al-Qur'an, 14 (1), 3243. 